\title{
Puunjalostusteollisuuden jäteliemipulveri märehtijäin rehuna
}

\author{
Maija-Liisa Salo, Matti Immonen ja Kaija Suomi \\ Yliopiston kotieläintieteen laitos, Helsinki
}

Saapunut 28. 2. 1973

\section{Nutritive value of ammonium spent suiphite waste liquor $\left(\mathrm{NH}_{3}-\mathrm{SSWL}\right)$ for ruminants}

\author{
Maija-Lissa Salo, Matti Immonen and Kaija Suomi \\ Department of Animal Husbandry, University of Helsinki
}

\begin{abstract}
The nutritive value of dried ammonium spent sulphite waste liquor was investigated. The waste liquor was a by-product of the birch wood manufacturing industry and was composed mainly of xylane and lignin. These substances largely occurred in such a form that the usual determinations revealed only a part of them. The nitrogen, sulphur and acetic acid contents in the different preparations were $4-7$ $\%, 4.5-9 \%$ and $0.5-7 \%$, respectively.

Digestibility experiments with sheep indicated that when the milk powder in a barleystraw-milk powder diet was replaced with the waste liquor amounting to $18 \%$ (level 1) and $9 \%$ (level 2) of the diet, the digestibility of the organic matter decreased from 84.0 $\%$ to $73.5 \%$ at level $1(\mathrm{P}<0.001)$ and from $82.1 \%$ to $77.8 \%$ at level $2(\mathrm{P}<0.001)$. The waste liquor diminished particularly the digestibility of the cell-wall substances. Thus the digestibility of crude fibre decreased from $46.3 \%$ to $15.8 \%$ at level 1 and from 37.8 to $29.4 \%$ at level $2(\mathrm{P}<0.001)$. The waste liquor itself did not contain any cellulose and hardly any crude fibre.

The digestibility of the waste liquor obtained by difference calculations was $36.6 \%$ at level 1 and $50.6 \%$ at level 2 . The feed unit values were 0.40 and 0.56 , respectively ( $1 \mathrm{fu}=0.7$ starch units). The utilization of nitrogen was good and the mineral balances were normal.

The palatability of the waste liquor was poor. The upper limit for acceptance by dairy cows was $7--8 \%$ of the concentrate, and even this concentration required a long transition period. It had no influence on the fat content of milk and the haematological values of the animals. Nor did it decrease the milk production if the concentration was so low that the feed intake remained adequate.

No noteworthy differences in the palatability were observed between various sulphite waste liquor products, the least palatable was that with the highest content of nitrogen and sulphur,
\end{abstract}


Puuaines koostuu kolmesta ryhmästä: selluloosasta, hemiselluloosasta ja ligniinistä. Niitä on havupuussa suunnilleen suhteessa $5: 2: 3$, lehtipuussa 5:3:2 (SALO 1965). Muita yhdisteitä puun kuiva-aineessa on sangen vähän.

Selluloosateollisuus kelpuuttaa tuotteeseensa vain selluloosan, ligniini ja hemiselluloosa liuotetaan pois. Kuitulevyjen valmistuksessa vaatimus ei ole yhtä ankara, mutta siinäkin puukuidut täytyy irroittaa ja tämä prosessi liuottaa hemiselluloosaa. Ainehukka puunjalostusteollisuudessa on siten suuri. Jäteliemen tavanomainen käyttömuoto on sen kuivaaminen polttoaineeksi, mutta myös muita ratkaisuja on etsitty. Eräs käyttökokeilu on jäteliemen kuivaaminen märehtijäin rehuksi.

Painemenetelmällä valmistetun kuitulevyn jäțeliemi on osoittautunut rehuna varsin käyttökelpoiseksi. Levyn valmistusprosessissa puukuidut irroitetaan kovan paineen avulla ilman kemikaaleja. Käsittely liuottaa hemiselluloosaa, mutta ilmeisesti vain varsin vähän ligniiniä. Jäteliemi haihdutetaan siirapiksi. Tätä siirappia (liquid hemicellulose, "Masonex») on hyvällä menestyksellä kokeiltu märehtijäin rehuna sekä USA:ssa (PERRY 1964, BARTLEY ym. 1968, Williams ym. 1969) että myös Suomessa (Tuori ja Lampila 1971). Rehuarvoltaan se on osoittautunut jokseenkin melassin veroiseksi, maittavuudeltaan sitä huonommaksi.

Kun puun prosessointiin käytetään kemikaaleja, joutuu jäteliemeen hemiselluloosan ohella ligniiniä ja kyseiset kemikaalit. Tätäkin tuotetta käytetään kuivattuna rehujen pelletoinnissa sideaineena. CROYLE ja LONG (1971) ovat tutkineet erään tällaisen tuotteen - ammonium lignosulfonaatin - käyttöarvoa märehtijäin rehuna ja todenneet sekä ruokintakokeissa että in vitro sulavuuskokeessa sen rehuarvon heikoksi.

Kirjoittajain tutkima tuote oli koivuraaka-aineesta ammonium neutraalisulfaattikeitossa muodostuvaa jätelientä. Keitossa liukenee vain noin $20 \%$ puusta, mm. ligniinistä vain pienimolekyylisin osa. Liemi kuivattiin tai haihdutettiin siirapiksi. Tutkimus käsitti lampailla suoritettuja sulavuus- ja tasekokeita, lypsylehmillä suoritettuja ruokintakokeita ja lihamulleilla tehtyjä maittavuuskokeita. Tarkoituksena oli selvitellä jätteen rehuarvoa, maittavuutta ja vaikutusta eläinten terveydentilaan; ylipäänsä saada selville, onko siitä märehtijäin rehuksi.

\section{Jäteliemipulverin koostumus}

Taulukosta 1 löytyy tuotteen valmistus- ja koostumustietoja, taulukoista 2 ja 3 kotieläintieteen laitoksessa suoritetut analyysit. Hiilihydraatit ja ligniini määritettiin SALOn (1965) menetelmillä, kivennäisaineista kationit AA1000 Techtron atomiabsorptiospektrofotometrillä ja fosfori TAYssKYn ja SHoRRin (1953) menetelmällä. Viralliseen rehuanalyysiin kuuluvat menetelmät olivat tavanomaisia.

Taulukossa 2 esitetään ravintoarvon kannalta tärkeimpien aineiden pitoisuudet neljästä sulavuuskokeella tutkitusta jäteliemipulverista tai -siirapista ja vertailun vuoksi myös painemenetelmällä saadusta USA:sta peräisin olevasta hemiselluloosasiirapista ja Turengin sokerijuurikasmelassista. 
Taulukko 1. Maittavuus- ja ruokintakokeissa käytetyt jäteliemipulverit.

Table 1. Ammonium spent sulphite waste liquor ( $\mathrm{NH}_{3}-\mathrm{SSWL}$ ) products used in palatability and feeding experiments.

\begin{tabular}{|c|c|c|c|c|c|c|c|c|}
\hline $\begin{array}{l}\text { Tunnus } \\
\text { Product }\end{array}$ & $\begin{array}{c}\text { Kuivaus- } \\
\text { lämpötila } \\
\text { sisään/ulos } \\
\text { Drying } \\
\text { temperature } \\
\text { in/out } \\
{ }^{\circ} \mathrm{C}\end{array}$ & $\mathrm{pH}$ & $\begin{array}{c}\text { Vesiliukoisuus } \\
\text { Water solubility } \\
\%\end{array}$ & $\begin{array}{l}\mathrm{SO}_{2} \\
\%\end{array}$ & $\begin{array}{c}\text { Kok. S } \\
\text { Total S } \\
\%\end{array}$ & $\mathrm{NH}_{3}$ & $\begin{array}{c}\text { Kok. N } \\
\text { Total } N \\
\%\end{array}$ & $\begin{array}{c}\text { Etikka- } \\
\text { happo } \\
\text { Acetic } \\
\text { acid } \\
\%\end{array}$ \\
\hline A & $275 / 125$ & 4.3 & 45.6 & 1.3 & 6.2 & 3.9 & 5.3 & 7.2 \\
\hline B & $300 / 160$ & 3.2 & 48.5 & 1.2 & 7.2 & 3.8 & 5.7 & 2.5 \\
\hline C & $400 / 160$ & 2.5 & 32.3 & 0.8 & 4.6 & 1.5 & 3.8 & 0.5 \\
\hline D & $270 / 120$ & 2.9 & 51.8 & 1.0 & 9.1 & 6.3 & 6.9 & 5.4 \\
\hline E & $270 / 120$ & 3.6 & 41.3 & 0.5 & 5.8 & 4.7 & 5.5 & 1.5 \\
\hline F & $300 / 150$ & 3.1 & 33.9 & 0.8 & 4.6 & 3.3 & 5.1 & 4.4 \\
\hline
\end{tabular}

Taulukko 2. Jäteliemituotteiden, „Masonex» hemiselluloosa siirapin ja sokerijuurikasmelassin koostumus.

Table 2. Chemical composition of $\mathrm{NH}_{3}-\mathrm{SSWL}$ products, liquid hemicellulose ("Masonex") and sugar beet molasses.

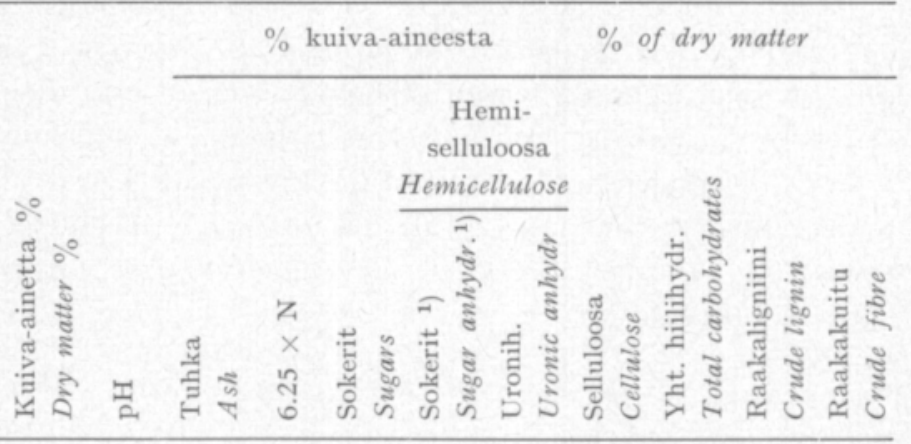

Jätetuotteet:

$\mathrm{NH}_{3}-S S W L$ products:

No I (jauhe, powder)

\begin{tabular}{rrrrrrrrrrr}
90.7 & 4.9 & 1.8 & 45.2 & 1.4 & 20.4 & 9.8 & 0.0 & 302 & 7.2 & - \\
94.8 & 4.5 & 1.6 & 37.8 & 1.4 & 20.3 & 9.7 & 0.0 & 30.0 & 7.4 & 0.8 \\
55.1 & 5.3 & 1.5 & 47.9 & $1 . ;$ & 18.6 & 11.4 & 0.0 & 30.0 & 7.1 & - \\
93.7 & 4.9 & 5.2 & 34.6 & 1.0 & 19.8 & 7.2 & 5.3 & 32.3 & 18.5 & 11.9 \\
63.0 & 6.5 & 6.9 & 0.3 & 30.5 & 26.0 & 2.5 & 0.0 & 59.0 & 3.6 & - \\
79.4 & 7.8 & 11.0 & 13.9 & 71.9 & 0.0 & 2.0 & 0.0 & 73.9 & 0.0 & - \\
\hline
\end{tabular}

, II ( " *)

" III (siirappi syrup)

- IV (o-turve 1: 1, peat)

"Masonex" (siirappi syrup)

Melassi Molasses

1) Eri sokerianhydridien osuus, \%: ksyloosi arabinoosi mannoosi galaktoosi + glukoosi

1) Distribution of sugar anhydrides, \%: xylose arabinose mannose galactose + glucose Jäteliemi $\mathrm{NH}_{3}$-SSWL ............. $85 \quad+\quad-\quad 4$.

Masonex ........................ $20 \quad 45$


Taulukko 3. Jäteliemituotteiden kivennäiskoostumus, $\mathrm{mg} / \mathrm{g}$ k.a.

Table 3. Mineral composition of $\mathrm{NH}_{3}$-SSWL products, $\mathrm{mg} / \mathrm{g}$ dry matter

\begin{tabular}{|c|c|c|c|c|c|}
\hline & $\mathrm{Ca}$ & $\mathrm{Mg}$ & K & $\mathrm{Na}$ & $\mathrm{P}$ \\
\hline No II............... & 2.60 & 0.75 & 1.95 & 0.15 & 0.30 \\
\hline , III .............. & 3.40 & 1.05 & 2.15 & 0.15 & 0.30 \\
\hline , IV ................ & 4.95 & 2.00 & 2.55 & 0.35 & 2.28 \\
\hline
\end{tabular}

Analyysituloksista käy ilmi, että jätepulverin hiilihydraattiaines koostuu lievällä happohydrolyysillä hydrolysoituvasta ksylaanista ja uronihapoista, pelkistävien sokerien asteelle saakka hajonnutta ainetta sen sijaan on hyvin vähän. Hiilihydraatti- ja ligniiniluvut ovat alhaisia mikä lienee tulkittava siten, että käsittely on muuttanut osan hemiselluloosasta sellaiseen muotoon että se ei hajoa pelkistäviksi sokereiksi. Muuttumisprosessista on merkkinä myös korkea uronihappopitoisuus, puussa uronihappoja on vajaa puolet siitä, mitä tässä tuotteessa. Mahdollisesti myös osa ligniinistä esiintyy niin pienimolekyylisessä muodossa, ettei liioin se tule tavanomaisilla menetelmillä määritetyksi. "Masonex'ssa" sen sijaan on varsin runsaasti pelkistyskykyistä hemiselluloosa-ainesta, siis muuttumattomassa muodossa olevia hiilihydraatteja. Hemiselluloosan koostumus paljastaa, että jäteliemipulveri on lehtipuusta, mutta "Masonex» ainakin pääosalta havupuusta (vert. SALO 1965). Taulukon kolmas aine, sokerijuurikasmelassi, koostuu pääosaltaan sakkaroosista.

Jäteliemipulverin typpi on peräisin keitossa käytetystä ammoniumsulfiitista, "Masonex» ei sisällä typpeä juuri lainkaan. Tuhkaa ja niin ollen eri kivennäiskomponentteja jätepulverissa on hyvin vähän (Taul. 3).

Jäteliemisiirappi-kasvuturpeen koostumusta tarkkailtaessa on syytä muistaa, että siinä on puolet turvetta.

\section{Sulavuuskokeet pässeillä}

Sulavuuskokeissa oli 4 pässiä, joista 3 kasvavaa ja 1 täysikasvuinen. Kokeet suoritettiin kvantitatiivisena, sekä valmistus- että keruukausi oli 8 tai 9 päivää. Samalla suoritettiin typpitasekoe ja eräillä näytteillä myös kivennäistasekoe. Perusrehuna oli ohrajauho $+100 \mathrm{~g}$ olkea sekä tarvittavat kivennäiset ja vitamiinit. Valkuaistäydennyksenä peruskokeissa oli kurrijauho, josta käytettiin taulukkotietojen sulavuusprosentteja. Varsinaisessa kokeessa kurrijauho korvattiin jätepulverilla tai -siirapilla. Kokeessa I sekä perusettä koerehu oli seoksena, jossa kurrijauhon/jätepulverin osuus oli $20 \%$. Tämä jätemäärä osoittautui liian korkeaksi: maittavuus oli heikko ja pässien sonta oli epänormaalin pehmeää. Koe toistettiin pienemmällä jätemäärällä: $800 \mathrm{~g}$ ohrajauhoa, $100 \mathrm{~g}$ olkea, $80 \mathrm{~g}$ kurrijauhoa/jätepulveria/p (Koe II). Näin alhaisena konsentraationa jätteestä ei ollut haittaa. Seuraavasta yhdistelmästä käy ilmi eri rehulajien osuus dieettien orgaanisesta aineesta: 
Ohra $\% \quad$ Olki ${ }^{1}{ }^{1}$ ) Kurrijauhe $\%$ Jätetuote $\%$

\begin{tabular}{|c|c|c|c|c|c|}
\hline Peruskoe & 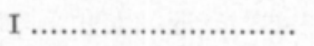 & 72.1 & 11.1 & 16.8 & - \\
\hline Jäte & I (jauhe I) $\ldots . \ldots \ldots . .$. & 71.1 & 11.0 & - & 17.9 \\
\hline Peruskoe & II $\ldots \ldots \ldots \ldots \ldots \ldots \ldots \ldots \ldots \ldots \ldots \ldots \ldots \ldots \ldots$ & 82.0 & 9.9 & 8.1 & - \\
\hline Jäte & (jauhe II) $\ldots \ldots \ldots \ldots \ldots$ & 81.5 & 9.7 & - & 8.8 \\
\hline , & III (siirappi) ........... & 83.0 & 10.0 & - & 7.0 \\
\hline , & IV $($, turve $) \ldots \ldots . .$. & 79.5 & 9.6 & - & $\left.10.9^{2}\right)$ \\
\hline
\end{tabular}

1) Kokeissa I ohranolki, kokeissa II-IV kauranolki

2) Puolet turvetta

Taulukossa 4 esitetään dieettien keskimääräiset sulavuudet. Taulukossa 5 jätepulverin tai -siirapin tai siirappi-turpeen orgaanisen aineen ja «raakaproteiinin» $(6.25 \times \mathrm{N})$ sulavuudet joka pässillä erikseen sekä keskiarvona. Taulukossa 6 on typpitaseet kasvavilta pässeiltä sekä osasta kokeita kivennäistaseet.

Taulukko 4. Rehuyhdistelmien keskimääräiset sulavuusprosentit.

Table 4. Average digestibility coefficients of different diets.

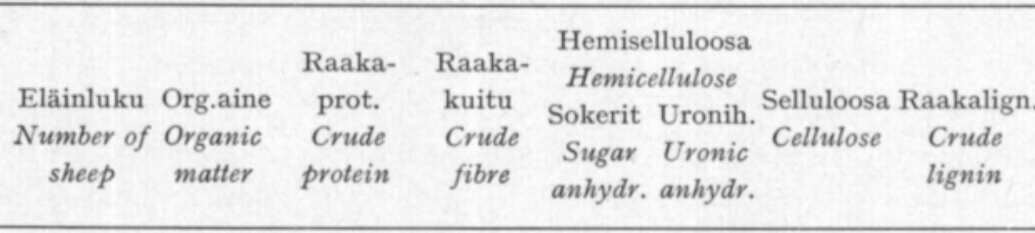

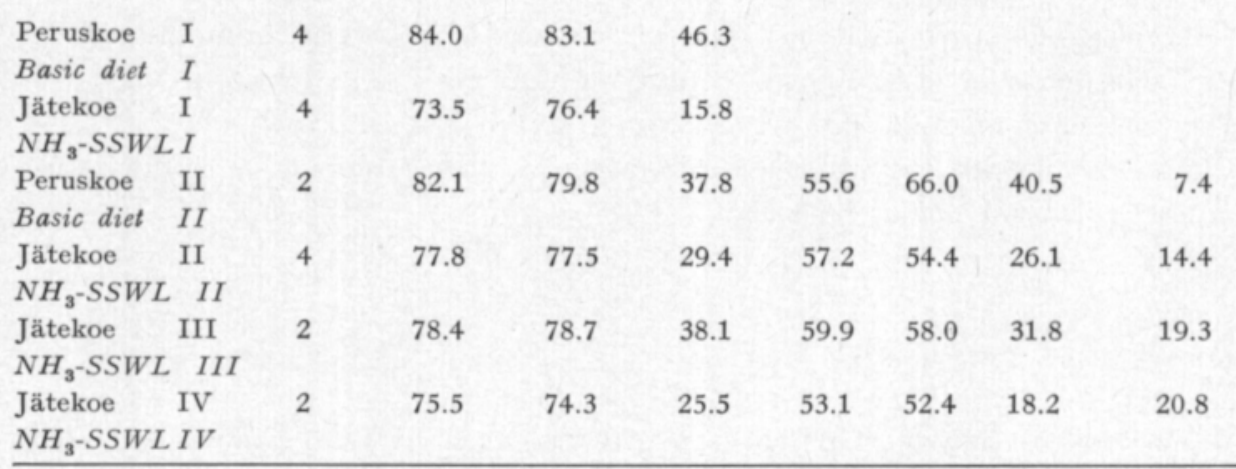

\section{Tulosten tarkastelu}

Taulukosta 4 voidaan ensinnäkin todeta, että jätepulveria sisältävän dieetin orgaanisen aineen sulavuus on sekä tasolla I että tasolla II erittäin merkitsevästi $(\mathrm{P}<0.001)$ huonompi kuin kurrijauhoa samassa suhteessa sisältävän kontrollidieetin. Edelleen käy ilmi, että suurempi jätekonsentraatio (Koe I) alentaa dieetin sulavuutta enemmän kuin pienempi (Koe II). Selvemmin tämä seikka käy ilmi taulukosta 5 , jossa on erotuksena laskettu jäteliemipulverin sulavuus: se on merkitsevästi $(\mathrm{P}<0.01)$ alempi dieetin sisältäessä jätettä noin $18 \%$ kuin $9 \%$. Ilmiö johtuu aivan ilmeisesti siitä, että 
Taulukko 5. Jäteliemituotteiden sulavuusprosentit eri kokeissa (suluissa tuotteen osuus dieetin orgaanisest $\iota$ aineesta).

Table 5. Digestibility coefficients of $\mathrm{NH}_{3}-\mathrm{SSWL}$ products in different trials (in parenthesis the proportion of $\mathrm{NH}_{3}-\mathrm{SSWL}$ in organic matter of diet).

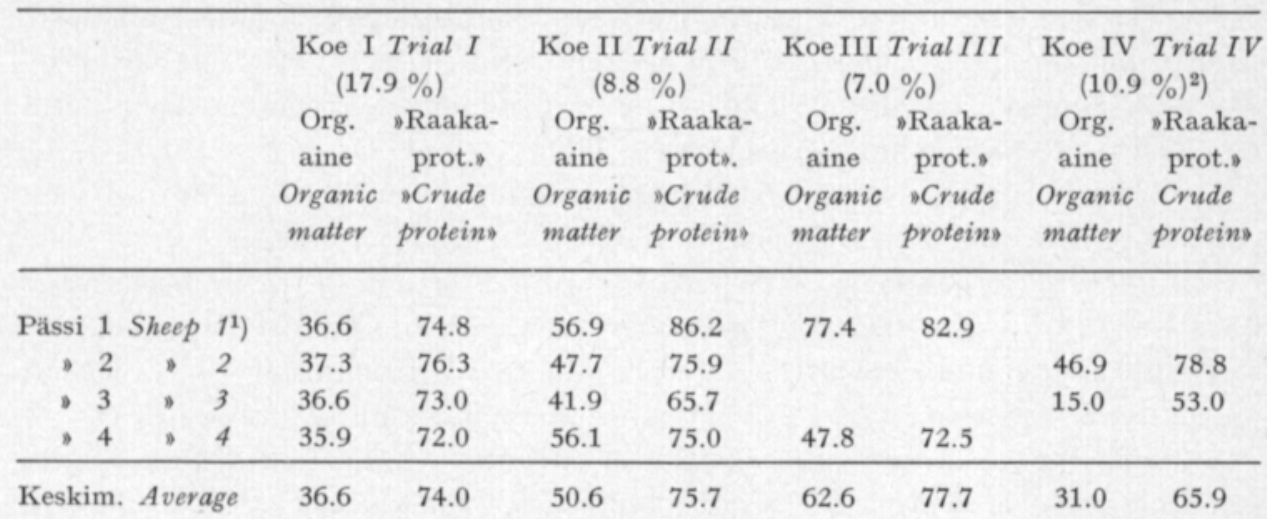

1) No 1 täysikasvuinen, muut kasvavia. No 1 adult, others still growing.

2) Puolet turvetta. Half peat.

Taulukko 6. Kasvavien pässien typpitase ja kaikkien kivennäistase.

Table 6. Nitrogen balance of growing sheep and mineral balance of all animals.

\begin{tabular}{|c|c|c|c|c|c|c|c|}
\hline & & \multicolumn{6}{|c|}{ Pidättyi keskimäärin $\mathrm{g} / \mathrm{p}$ - Average retention g/day } \\
\hline & & $\mathrm{N}$ & $\mathrm{Ca}$ & $\mathrm{Mg}$ & K & $\mathrm{Na}$ & P \\
\hline Peruskoe & I & 4.24 & & & & & \\
\hline Basic diet & $I$ & & & & & & \\
\hline Jätekoe & I & 3.27 & & & & & \\
\hline $\mathrm{NH}_{3}-\mathrm{SSWL}$ diet & $I$ & & & & & & \\
\hline Peruskoe & II & 3.67 & -0.07 & +0.66 & +0.71 & -0.65 & -0.13 \\
\hline Basic diet & $I I$ & & & & & & \\
\hline Jätekoe & II & 6.17 & +0.61 & +0.16 & +0.25 & -0.17 & -0.12 \\
\hline $\mathrm{NH}_{3}-\mathrm{SSWL}$ diet & $I I$ & & & & & & \\
\hline Jätekoe & III & 2.78 & +1.07 & +0.50 & -0.73 & +0.73 & +0.65 \\
\hline $\mathrm{NH}_{3}-\mathrm{SSWL}$ diet & $I I I$ & & & & & & \\
\hline Jätekoe & IV & 2.23 & +2.24 & +0.40 & -0.82 & -0.18 & +0.47 \\
\hline $\mathrm{NH}_{3}-\mathrm{SSWL}$ diet & $I V$ & & & & & & \\
\hline
\end{tabular}

jäteliemipulveri heikentää pötsifermentaatiota ja inhiboiva vaikutus on sitä voimakkaampi, mitä korkeampi dieetin jätekonsentraatio on.

Sulavuutta inhiboiva vaikutus kohdistuu erikoisesti kuituainekseen, kuten taulukon 4 raakakuitu- ja selluloosa-arvoista näkyy. Esimerkiksi raakakuidun sulavuudessa on molemmilla tasoilla perus- ja koedieetin välillä erittäin merkitsevä ero $(\mathrm{P}<0.001)$ ja yhtä merkitsevä on sulavuuden aleneminen siirryttäessä koedieetissä $9 \%$ :n tasolta $18 \% \mathrm{n}$ tasolle $(\mathrm{P}<0.001)$. Jätepulveri ei sisällä selluloosaa eikä juuri raakakuituakaan, joten sulavuuden 
aleneminen on kohdistunut ohran ja oljen kuituainekseen. Hemiselluloosassa perusrehun sulavuuden mahdollinen aleneminen ei näy, sillä jäte sisältää noin $30 \%$ kuiva-aineesta kemiallisesti hyvin helppoliukoista hemiselluloosaa. Raakaligniinin sulavuus päinvastoin nousee, mutta sille ei kannata panna paljon arvoa, koska ligniini on koostumukseltaan sangen epämääräinen ainesosa. Nousu voidaan tulkita niinkin, että heikentyneen fermentaation vuoksi jätedieetistä peräisin olevassa sonnassa on vähemmän mikrobiainesta ja siitä muodostuvaa valeligniiniä (vert. SALO 1965).

Koe kasvuturpeeseen imeytetyllä jätesiirapilla (Taul. 4, Koe IV) oli vain omiaan osoittamaan, että turpeesta ei ole märehtijäin rehuksi.

Taulukosta 5 nähdään, että pässien välillä oli suuria yksilöllisiä eroja. Täysikasvuinen pässi (no 1) sulatti jätettä paremmin kuin kasvavat; erikoisesti siirappimuodossa tarjottua jätettä, jota rehuyhdistelmässä oli vain $7 \%$ orgaanisesta aineesta, se sulatti paljon paremmin kuin kasvava pässi.

Jätedieetin raakaproteiinin sulavuus osoittautui hyväksi, vain korkea jätepitoisuus (Koe I) alensi sitä mainittavammin. Typpitasekoe (taul. 6) osoitti, että pässit pystyivät myös sangen hyvin käyttämään typen hyväkseen. Erikoisesti kokeessa II, jossa jätepulveria oli noin $9 \%$, typpitase muodostui erittäin hyväksi. Selitykseksi pätee ilmeisesti sama, mikä on esitetty säilörehun lisäaineiden vertailussa: kun lisäaine tietyissä rajoissa huonontaa pötsifermentaatiota, säästyy rehun proteinia mikrobihajotukselta ja typpitase paranee (SYRJÄLÄ 1972).

Koeryhmässä II suoritettiin myös kivennäistasekoe (Taul. 6). Tulokset kurrijauhe/jätepulveridieeteillä eivät poikenneet oleellisesti toisistaan. Voitiin todeta, että jäteliemipulveri ei 7-9\%:n tasolla vaikuta eläimen kivennäistaseeseen.

Pässeiltä tutkittiin hemoglobiini ja hematokriitti heti sen jälkeen, kun koko koeohjelma oli viety läpi. Molemmat arvot olivat normaalit.

Miksi jäteliemipulveri sitten on huonosti maittavaa, aiheuttaa jo 20-prosenttisena seoksena lievää ripulia ja alentaa kuituaineksen sulavuutta sitä enemmän, mitä enemmän tuotetta rehuun on lisätty? Vastaus on vain arvailua. Ensimmäiseksi tietenkin epäillään kemikaaleja, joita käytetään puun prosessoinnissa, erikoisesti korkeaan rikkipitoisuuteen on kiinnitetty huomiota. Toinen mahdollisuus on puun omista aineosista - ehkä yhdessä lisättyjen kemikaalien kanssa - prosessoinnissa mahdollisesti muodostuneet bakterisidiset yhdisteet. Esimerkiksi ligniinistä saattaa molekyylien osittain hajotessa muodostua mikrobien kasvua inhiboivia aineita, sisältyyhän ligniinimolekyyliin mm. fenoli- ja aldehydiryhmiä. Toiselta puolen tiedetään, että pötsimikrobit reagoivat herkästi moniin vieraisiin aineisiin; esimerkkinä tästä on formaldehydi, joka jo alhaisena konsentraationa voimakkaasti alentaa pötsifermentaatiota ja rehun sulavuutta (Hoghes ja Williams 1971). Haittatekijää ei kokeessa enemmälti pyritty identifioimaan, todettiin vain, että jäteliemituotteissa on jokin pötsifermentaatiota inhiboiva aine, jonka eläimet ilmeisesti aistivat ja sen vuoksi vieroksuvat tuotetta. 
Rehuyksikköarvon laskeminen edellämainittujen kokeiden perusteella on tietyssä määrin arviokauppaa. Orgaaninen aine kuuluu käytännöllisesti katsoen kokonaisuudessaan ryhmään raakahiilihydraatit, sillä tuotteen sraakaproteiini» on ammoniakkityppeä kerrottuna tavanomaisella raakaproteiinikertoimella ja rasvaa jäte ei sisällä. Rehutaulukoista ei löydy tuotetta, joka antaisi vihjeen arvoluvusta (raakakuitua tuote ei sisällä). Sokerijuurikasmelassi lienee lähinnä, sille on ilmoitettu arvoluku 0.87. Tätä arvolukua käyttäen saadaan kokeiden I ja II keskimääräisten sulavuusprosenttien mukaan jäteliemipulverille (90\% kuiva-ainetta) seuraavat rehuarvot:

\begin{tabular}{|c|c|c|c|c|c|}
\hline & & & $\begin{array}{l}\text { Jätteen org. ainetta } \\
\text { dieetin org. aineesta }\end{array}$ & Ry-arvo & Korvaus! \\
\hline Koe & I & ............. & $1 / 9 \%$ & 0.40 & 2.5 \\
\hline , & II & 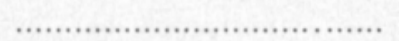 & 8.8, & 0.56 & 1.8 \\
\hline & III & (siirappi) & 7.0 (täysikasvuinen pässi) & $\begin{array}{l}0.85 \\
0.53\end{array}$ & 1.2 \\
\hline
\end{tabular}

Jätesiirappikokeessa (III) oli vain kaksi eläintä (muissa neljä) ja niiden sulavuustulokset poikkesivat toisistaan hyvin paljon. Sen vuoksi niiden tulos on laskettu erikseen. Siirapille on ry-arvo laskettu $90 \%$ ja kuiva-aineen mukaan, jotta on saatu pulverin kanssa vertailukelpoisia lukuja.

Tuloksista voitaneen päätellä, että jäteliemipulverin ja -siirapin ry-arvo riippuu sen määrästä dieetissä: jos sitä on rehuyhdistelmässä noin $18 \%$ orgaanisesta aineesta, on korvausluku huonon heinän luokkaa eli 2.5. (Näin konsentroituna eläimet syövät sitä vain, jos muuta rehua ei anneta ja silloinkin vastahakoisesti). Jos määrä pudotetaan puoleen, on korvausluku 1.8. Vanhalla pässillä siirappimuodossa $7 \%$ osuutena dieetin orgaanisesta aineesta annettu jäte oli ry-arvoltaan jopa kauran veroista, mutta kasvava pässi antoi samalle tuotteelle korvausluvun 1.9. Yksilölliset erot olivat yleensäkin hyvin suuria ja voi olla, että tottuminenkin vaikutti jonkin verran tulokseen. Tässäkin koesarjassa sulavuus parani koejaksojen myötä, mikä seikka kuitenkin tulkittiin jätepulverin vähentämisen ansioksi, koska määrän alentaminen poisti tuotteen ruoansulatukselliset haittavaikutukset. Lisättäköön vielä, että itse jätteen sulavuus tuskin suuresti vaihtelee, vaihtelu johtuu sen vaikutuksesta perusrehun sulavuuteen, mikä differenssikoetta käytettäessä tulee lasketuksi perusdieettiin lisätyn aineen osalle.

\section{Ruokintakokeet lypsylehmillä}

Ensimmäinen koe suoritettiin kolmella lehmällä, jotka olivat poikineet noin $4.5 \mathrm{kk}$ aikaisemmin. Ne olivat $2-3$ kertaa poikineita ja terveitä. Lehmät olivat edellä olleet ruokintakokeessa, missä niiden syönti, maitòtuotos ja veriarvot oli kontrolloitu. Maitotuotos koetta aloitettaessa oli $15-20 \mathrm{~kg} / \mathrm{p}$. Leh- 
mät olivat saaneet säilörehua, heinää, melassileikettä, kaura-ohraseosta, soijarouhetta ja kivennäisseosta. Kokeessa jätettiin soijarouhe pois ja valkuaisvähennys korvattiin koerehulla ja lisätyllä säilörehulla. Koerehu sisälsi jäteliemipulveria ja viherjauhoa suhteessa $1: 1$, se sekoitettiin väkirehuun. Koerehun määrää lisättiin kahtena ensimmäisenä päivänä $350 \mathrm{~g}$, sitten vähemmän, koska lehmät jättivät väkirehua ja ehtyivät. Määrä rajattiin sitten $1 \mathrm{~kg}: \mathrm{ksi} / \mathrm{p}$ ja tämän lehmät yleensä söivät ja maidontuotanto pysyi alkupudotuksen jälkeen tasaisena, kuten kuvasta 1 käy ilmi. Siinä lehmien ry- ja puhtaan jätepulverin syönti sekä maitotuotos esitetään kymmenpäivittäin päivää kohti laskettuna keskiarvona.

Koe osoitti että siirto jätepulveriin tapahtui liian nopeasti. Väkirehun syönti ja maitotuotos laski siirtokautena jyrkästi. Kun koerehun määrää ei enää nostettu ja lehmät tottuivat uuteen rehuun, ei tuotos enää laskenut, mutta ei liioin noussut ennalleen. On tosin huomattava, että lehmien poikimisesta oli kulunut jo noin $5 \mathrm{kk}$, eikä heruminen takaisin tässä laktaatiovaiheessa normaalistikaan tapahdu helposti.

Maidosta tehtiin kerran viikossa rasvamääritys kolmen peräkkäisen päivän sekanäytteestä ja rasvaprosentit näkyvät maitotuotosta kuvaavan pylvään päällä numeroina. Jätepulverin syötöllä ei ollut sen mukaan vaikutusta maidon rasvaprosenttiin.

Lehmistä otettiin ennen koetta, muutamaan kertaan koeaikana ja sen jälkeen verinäytteet, joista määritettiin erilaisia orgaanisia ja epäorgaanisia komponentteja. Ketoaineet määritettiin BAKKerin ja WHiten (1957) menetelmällä, glukoosi Nelsovin (1944) ja Somogyı'n (1945) menetelmällä ja kivennäisaineet jo aiemmin mainituilla menetelmillä. Tulokset näkyvät taulukossa 7. Mitään vaikutusta veren koostumukseen ei ilmennyt.

Toisessa kokeessa siirto järjestettiin loivaksi. Siihen otettiin kaksi lehmää, joilta niinikään edellä oli kontrolloitu syönti, tuotos ja veriarvot. Lehmät olivat poikineet $7-8$ viikkoa aikaisemmin, toinen oli ensikko, toinen 4 kertaa poikinut, molemmat korkeatuottoisia. Lehmien rehut olivat samat kuin edellä. Tällä kertaa mitään ei jätetty pois, vaan puhdasta jäteliemipulveria (näyte A, taul. 1) annettiin väkirehuseoksessa lisäten määrää 50 g:lla joka toinen päivä. Ry- ja A-pulverin syönti sekä maitotuotos kymmenen päivän keskiarvoina ja maidon rasvapitoisuus näkyy kuvassa 2 .

Näin varovasti lähtien ei syöntivaikeuksia eikä liioin maidontuotannon laskua ilmennyt ennenkuin päästiin lähes kilon jätepulverimäärään päivässä. Kun määrä oli noussut $1000 \mathrm{~g}: \mathrm{ksi} / \mathrm{p}$, koe keskeytettiin, koska silloin lehmät jättivät väkirehuja niin paljon, että maitotuotos alkoi aleta.

Jätepulveri ei tässäkään kokeessa vaikuttanut maidon rasvapitoisuuteen eikä liioin veriarvoihin, jotka nähdään taulukossa 7. Ne vähäiset hemoglobiinin ja hematokriitin alenemiset, jotka kokeen aikana tapahtuivat, ovat Viikin karjassa normaalistikin laktaation edetessä todettu ilmiö. Veren hivenainepitoisuuksien vaihtelu on niinikään normaali ilmiö ja suuruusluokka on sama, mikä Viikin lehmillä yleensä on todettu. 


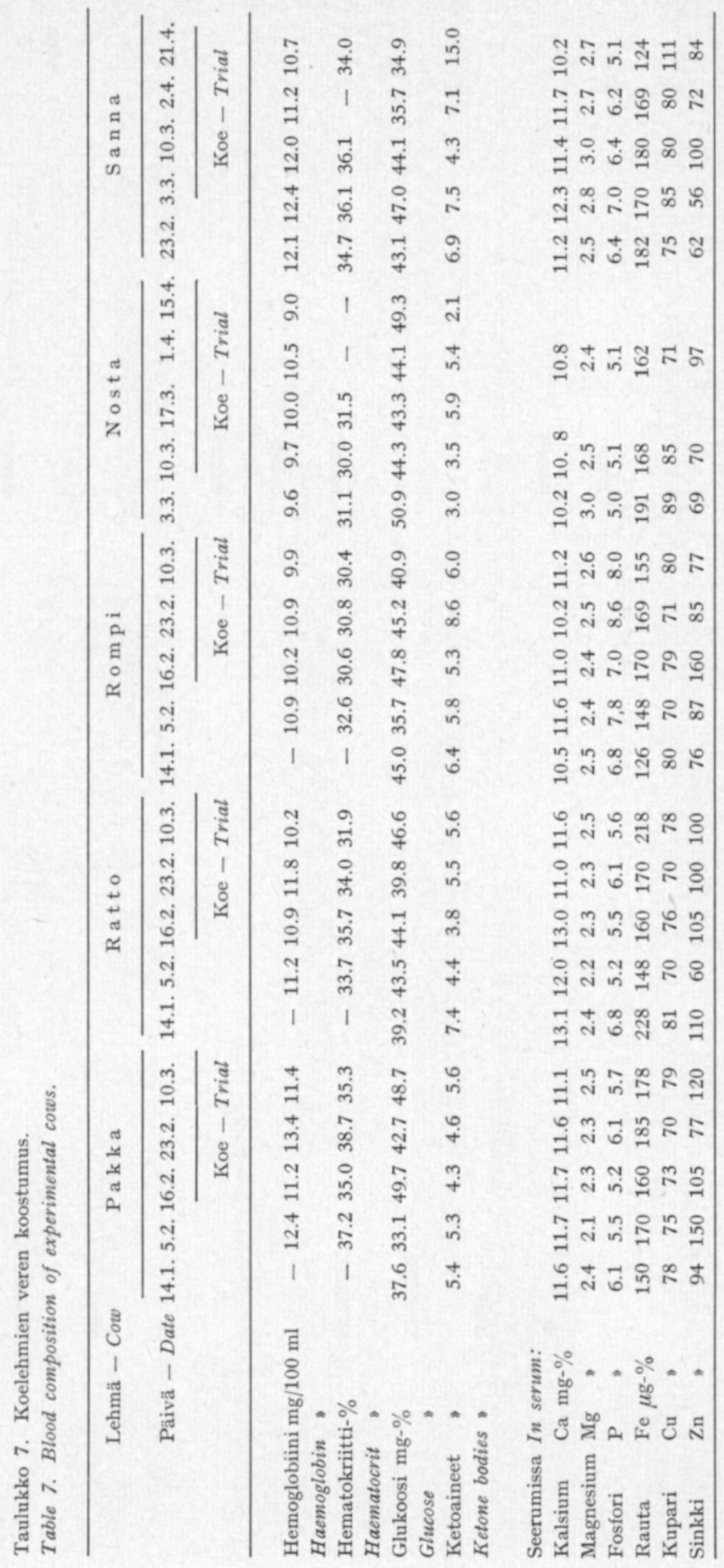




$\square$ maito

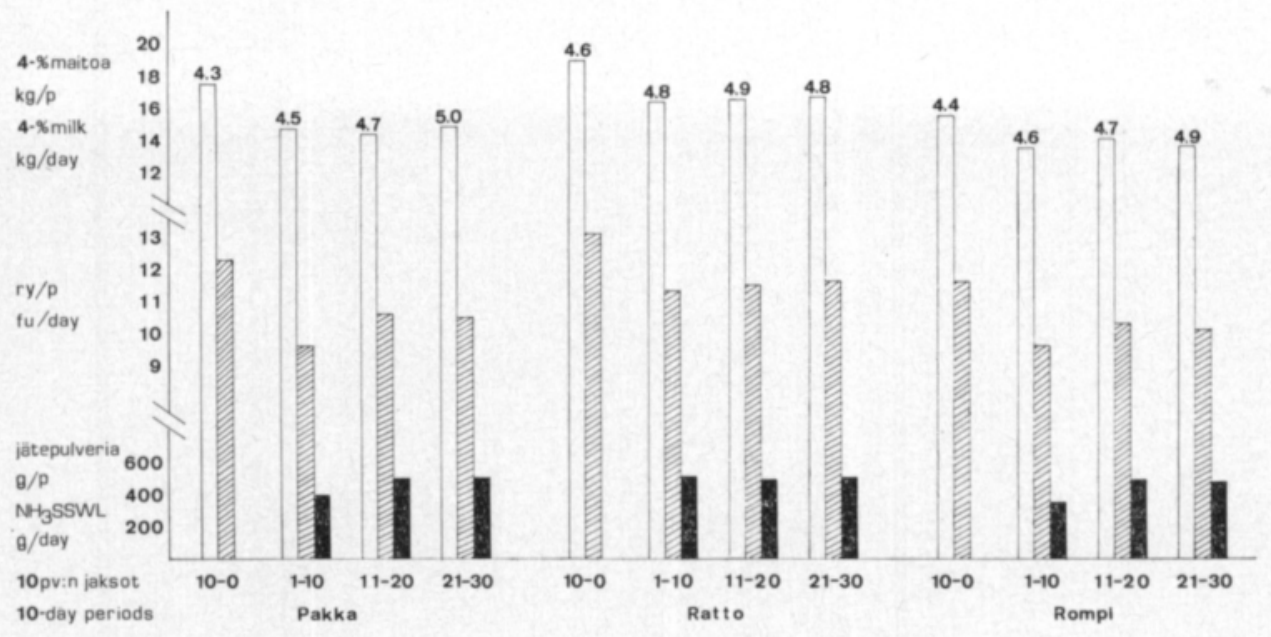

Kuva 1. Jäteliemipulverin vaikutus lehmien syöntiin ja maidontuotantoon, kun siirto tapahtui nopeasti.

Figure 1. The effect of the $\mathrm{NH}_{3}-\mathrm{SSWL}$ product on the feed intake and milk production of cows, when the transition period was short.

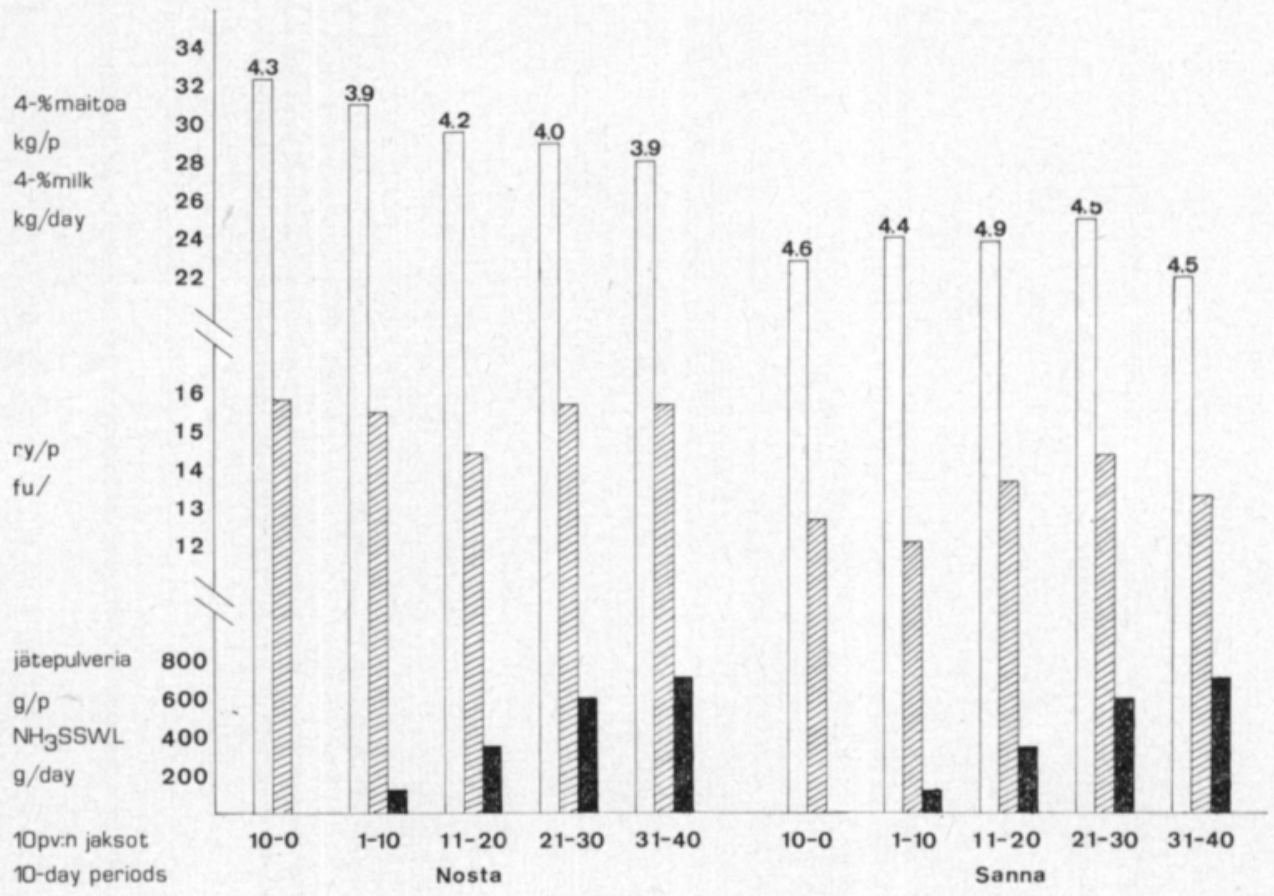

Kuva 2. Jäteliemipulverin vaikutus lehmien syöntiin ja maidontuotantoon, kun siirto tapahtui hitaasti.

Figure 2. The effect of the $\mathrm{NH}_{3}-\mathrm{SSWL}$ product on the feed intake and milk production of cows, when the transition period was long. 
Maittavuuskokeiden tarkoituksena oli saada selville, mikä valmistustapa anțaisi maittavinta pulveria ja paljonko eläimet sitä vapaaehtoisesti söisivät. Kokeiltavina olivat taulukossa 1 esitetyt tuotteet, joita merkittiin tunnuksin A-F.

Kokeet suoritettiin pihatossa useana jaksona. Makutuomareina oli 7-11 lihamullia, ikä eri koejaksoina 6-12 kk. Mullit saivat vapaasti säilörehua ja kaurajauhoa sekä vähän heinää. Jätepulveri oli 10 - tai 20-prosenttisena kaurajauhoseoksena tarjolla muovilaatikoissa. Aluksi vertailtiin eriä A, B ja C, sitten eriä D, E ja F. Ensimmäisessä jaksossa eri tuotteiden maittavuudessa ei ollut suuria eroja ja muutaman päivän jaksoina luvut menivät eri kerroilla ristiin 35 päivän loppujaksona jo lähes vuoden ikäiset sonnit söivät 20-prosenttisessa seoksessa eri valmisteita puhtaaksi pulveriksi laskettuna seuraavasti:

\begin{tabular}{|c|c|c|c|}
\hline Jätepulveri & 43 & $\mathrm{~g} /$ eläin/p & \\
\hline , & 43 & , & Yhteensä $122 \mathrm{~g} /$ eläin $/ \mathrm{p}$ \\
\hline , & 36 & , & \\
\hline
\end{tabular}

Tämä oli vapaaehtoisen syönnin maksimi tottumisen jälkeen. Kuten näkyy, selviä eroja tuotteiden välille ei tullut.

Lyhyessä jaksossa, jossa kaurajauhon antoa vähennettiin kilolla sonnien normaalisyönnistä ja 20 -\% seosta oli vapaasti tarjolla, oli syönti parhaillaan noin $150 \mathrm{~g}$ jätepulveria/eläin/p.

D, E ja F pulverikokeessa oli 6 -8 kk:n ikäisiä jauhoon tottumattomia eläimiä. Lisäksi ilmat olivat lämmenneet, ja mahdollisesti tuotteen haju tuntui pistävämpänä. Jätepulveria kului parhaimmillaan yhteensä $62 \mathrm{~g} / \mathrm{eläin/p}$. Näistä seoksista D oli ylivoimaisesti heikoimmin maittava, paras oli F, mutta suurta eroa E:n ja F:n välillä ei ollut.

Maittavuuskoe osoitti, että $10-20$ prosenttisena seoksena kaurajauhon joukossa jäteliemipulveri maittoi lihamulleille varsin heikosti, kun niillä oli vapaasti saatavana puhdasta kaurajauhoa ja säilörehua. Eri tuote-erien maittavuudessa oli vain pieniä eroja lukuunottamatta jauhoa D, joka jäi melkein koskematta. Huomattakoon, että sonnit saivat riittävästi raakaproteiinia säilörehusta ynnä kaurasta, joten typpivajausta niiden ei jäterehulla tarvinnut täyttää.

\section{Tiivistelmä ja johtopäätökset}

Tutkimus käsitteli koivuraaka-aineesta ammonium neutraali-sulfiittikeitossa muodostuvan kuivatun jäteliemen käyttöä märehtijäin rehuna. Tuote koostui pääasiassa ksylaanista ja ligniinistä. Kumpikin aine oli suureksi osaksi niin muuttuneessa muodossa, että tavanomaiset määritysmenetelmät ilmaisivat niistä vain osan. Typen määrä vaihteli erilaisissa valmisteissa rajoissa $4-7 \%$, rikin $4.5-9 \%$ ja etikkahapon $0.5-7 \%$ kuiva-aineesta.

Sulavuuskokeet lampailla osoittivat, että kun ohra-olki-kurrijauhe yhdistelmässä kurrijauhe korvattiin jäteliemipulverilla, dieetin orgaanisen aineen sulavuus aleni $18 \%$ :n tasolla (I) $84.0 \%$ :sta $73.5 \%$ :iin $(\mathrm{P}<0.001)$ ja $9 \%$ :n tasolla (II) $82.1 \%$ :sta $77.8 \%$ :iin $(\mathrm{P}<0.001)$. Jätepulveri alensi erikoisesti dieetin kuituaineksen sulavuutta. Niinpä rakakuidun sulavuus aleni I tasolla 
$46.3 \%$ :sta $15.8 \%$ :iin ja II tasolla $37.8 \%$ :sta $29.4 \%$ :iin. Ero sulavuuden ja samoin tasojen välillä oli erittäin merkitsevä $(\mathrm{P}<0.001)$. Jäteliemipulveri itsessään ei sisältänyt selluloosaa eikä juuri rakakuituakaan.

Erotuksena laskien saatiin jäteliemipulverin sulavuudeksi I tasolla $36.6 \%$ ja II tasolla $50.6 \%$. Ry-arvot olivat vastaavasti 0.40 ja 0.56 . Typen hyväksikäyttö oli hyvä ja eläinten kivennäistase normaali, samoin veriarvot.

Sekä sulavuuskokeet että lypsylehmillä ja lihasonneilla tehdyt ruokintakokeet osoittivat, että jäteliemipulveriin ei ainakaan nyt kokeilluissa muodoissa kannata kiinnittää suuria toiveita. Sen ry-arvo on ilmeisen heikko ja vähänkin suurempina konsentraatioina tuote heikentää rehun maittavuutta ja sulavuutta. Jo yksin heikko maittavuus määrää käytön ylärajaksi 5-7\% väkirehusta ja tälläkin tasolla siirron täytyy tapahtua hitaasti.

Eläinten terveydentilaan jätepulveri ei parin kuukauden koeaikana näyttänyt vaikuttavan haitallisesti. Se ei myöskään vaikuttanut maidon rasvaprosenttiin eikä liioin maitotuotokseen silloin, kun konsentraatio oli niin alhainen, ettei se vähentänyt syöntiä. Tästä huolimatta sen rehuksikäyttö on kyseenalaista. Korkeintaan sellaisissa oloissa, joissa lypsylehmien tai lihamullien valkuaistarvetta on vaikea tyydyttää, sitä voisi ajatella väkirehuun $5-7$ prosenttisena seoksena. Tämä määrä nostaisi seoksen raakavalkuaispitoisuutta $2-21 \frac{1}{2}$ \%-yksiköllä, mikä merkitsisi korkeatuottoisilla lypsylehmillä 2-3 maitokiloon päivittäin tarvittavaa raakavalkuaismäärää. Eri asia on, kannattaako tuotetta valmistaa pelkästään typenlähteeksi , kun kilpailijana on hinnaltaan edullinen urea.

\section{KIRJALLISUUTTA}

BAKKeR, N. \& White, R. R. 1957. A simplified micro-method for the colorimetric determination of total acetone bodies in blood. N. Z. J. Sci. 38: 1001-1008.

Bartley, E. E., Farmer, E. L., Frost, H. B. \& Dayton, A. D. 1968. Comparative value of dry and liquid hemicellulose extract and liquid cane molasses for lactating dairy cows. J. Dairy Sci. 51: 706-709.

Croyle, R. C. \& LoNG, T. A. 1971. Nutritive evaluation of ammonium lignin sulfonate. J. Anim. Sci. 33: 313 .

Hughes, J. G. \& Williams, G. L. 1971. The effect of formaldehyde treatment of protein supplements upon their in vitro fermentation and utilization by sheep. Proc. Nutrit. Soc., London 30: $41 \mathrm{~A}-42 \mathrm{~A}$.

Nelson, N. 1944. A photometric adaptation of Somogyi method for the determination of glucose. J. Biol. Chem. 153: 375-380.

Perry, T. W. 1964. New wood molasses (Hemicellulose extract) equivalent to cane molasses for beef cattle. Feedstuffs 36 No 46 .

SALO, M.-L. 1965. Determination of carbohydrate fractions in animal foods and faeces. Acta Agr. Fenn. 105: 1-102.

Somogyi, M. 1945. A new reagent for the determination of sugars. J. Biol. Chem. 160: $61-68$.

SYRJÄLÄ, L. 1972. Effect of different sucrose, starch and cellulose supplements on the utilization of grass silages by ruminants. Ann. Agric. Fenn. 11: 199-276.

TAUssky, H. H. \& ShorR, E. 1953. A microcolorimetric method for the determination of inorganic phosphorus. J. Biol. Chem. 202: 675-685.

TUORI, M. \& Lampila, M. 1971. Puusta eristetty hemiselluloosa lypsykarjan ruokinnassa. Koetoim. ja Käyt. 28: 30 .

Williams, D. L., Moore, J. D., Martin, L. C. \& Tillman, A. D. 1969. Studies on liquid hemicellulose and cane molasses in urea-containing diets. J. Anim. Sci. 28: 125. 